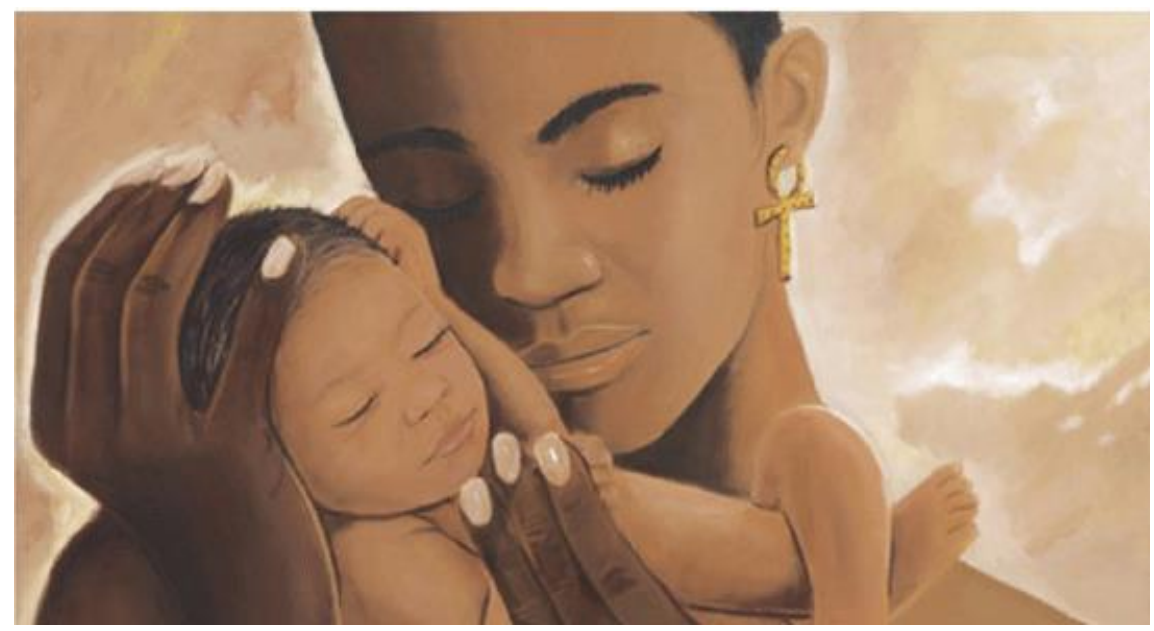

\title{
Sujeito histórico e amor eterno: a significação da figura materna em músicas sertanejas
}

Historic subject and mother`s love: the meaning of the maternal figure in country songs

\author{
Maciel Francisco dos Santos* \\ Telma Domingues da Silva**
}

\section{Resumo:}

Com base na Análise de Discurso francesa, este trabalho busca compreender, nas músicas sertanejas, o funcionamento de um discurso sobre o amor de mãe e um discurso de amor de filho, tomando como corpus cinco canções do estilo que produzem sentidos enquanto discurso amoroso no âmbito da relação filho/mãe. A análise partiu do estudo das condições de produção da música sertaneja e da relação que esta tem com a cultura caipira, por um lado, e, por outro lado, com os processos de urbanização. Procuramos compreender a significação da mãe nas canções analisadas, atentando para o fato de que o sujeito é condicionado sócio-historicamente e, assim sendo, consideramos a produção de música sertaneja e a inserção do locutor sertanejo na cultura caipira como constitutivas dessa significação. Através de recortes, mostramos um locutor sertanejo que, através de canções, demonstra seu amor por sua mãe, e que esse amor é enaltecido devido a fatores como a separação, aparecendo também associado ao discurso religioso.

Palavras chaves: Discurso amoroso; Locutor sertanejo (música sertaneja); Discurso caipira

Abstract: Based on the French Discourse Analyzes, this essay aims to comprehend on country songs, how the discourse about mother`s love and son`s love discourse work, considering as the corpus five songs of this style which produce meanings while lovely discourse on the scope of the mother/son`s relation. This analysis comes from the study of the conditions of the production of country music and from the relationship it has with the country culture on the one hand and the process of urbanization on the other. We try to comprehend the meaning of the mother on the analyzed songs, paying attention on the fact that the subject is socio-historically conditioned and, this way, we consider the production of country music and the insertion of the countryman speaker on country culture as constitutive of this meaning. With cuts, we show a countryman speaker that, through songs, demonstrate his love for his mother, and that this love is extolled due to facts such as divorce, also appearing related to religious discourse.

Key-words: Lovely discourse; Country man speaker (country music); Country discourse.

\footnotetext{
* Mestrando do Programa de Pós Graduação em Ciências da Linguagem da UNIVÁS macielfsantos@gmail.com

*** Docente do Programa de Pós Graduação em Ciências da Linguagem da UNIVÁS telmadds@gmail.com
} 


\section{Introdução}

O amor é tema de muitas canções, nos mais variados estilos musicais. Embora nessa formulação (a canção popular) predomine o cantar o (ou sobre o) amor conjugal, observa-se a ocorrência, no contexto da música sertaneja, de letras de música que abordam o amor de filho para mãe e/ou o amor de mãe para filho. Na realidade, esse tema é recorrente nas letras de música sertaneja, especialmente nas mais antigas, e é provável que esse seja o estilo musical mais dedicado a enaltecer a figura materna.

Esta análise teve início a partir de uma pesquisa desenvolvida no contexto do Mestrado em Ciências da Linguagem/ UNIVAS. ${ }^{1}$ A partir da análise de discurso, e tendo em vista trabalhos de pesquisa nesse contexto, como os desenvolvidos pelo Laboratório de Estudos Urbanos - Labeurb/ Unicamp (cf., por exemplo, ORLANDI 2001 e 2004), o espaço é compreendido em sua simbolização por e para o sujeito. Nas letras de música sertaneja, produz-se o urbano e o rural como lugares opostos, através de elementos que contrastam.

Com esta reflexão, buscamos compreender, nas músicas sertanejas, o funcionamento de um discurso sobre o amor de mãe e um discurso de amor de filho, tomando como corpus cinco canções do estilo que produzem sentidos enquanto discurso amoroso no âmbito da relação filho/mãe. ${ }^{2}$ A análise partiu do estudo das condições de produção da música sertaneja, da relação que esta tem com uma "origem caipira" do sujeito, por um lado, e, por outro lado, com os processos de urbanização.

Tendo como objetivo compreender o discurso amoroso de um sujeito filho, atentamos para o fato de como a mãe é significada nas letras que escolhemos: a significação é produzida a partir do filho, locutor dessa enunciação específica, a canção sertaneja.

A partir da leitura de Guimarães (2010), que aborda a poesia de uma perspectiva enunciativa, podemos compreender um certo lugar de fala do sujeito da enunciação, no caso, o locutor poeta. Para a análise que aqui realizamos, o sujeito da enunciação pode ser pensado como locutor sertanejo, locutor específico de um tipo de enunciação poética, que ocorre no contexto da música sertaneja, contexto discursivo marcado pelo

\footnotetext{
1 Trata-se da pesquisa "O contraste entre campo e cidade nas músicas sertanejas", em que buscamos compreender a significação dos espaços rural e urbano nas letras de música sertaneja, que foi desenvolvida por mim como pesquisador no projeto "Discurso jornalístico, mídia e sujeito", coordenado pela Prof. ${ }^{a}$ Dr. ${ }^{a}$ Telma Domingues da Silva, na Universidade do Vale do Sapucaí (Univás). E-mail: macielfsantos@gmail.com.

${ }^{2}$ Mamãe, Mamãe, Mamãe, gravada em 1964 por Tonico e Tinoco; Mãe Amorosa, gravada em 1973 por Abel e Caim; No Dia Em Que Saí de Casa, gravada por Zezé Di Camargo e Luciano em 1994; Mãe, gravada por Lucas e Luan em 1997; Mãe, gravada por Rick e Renner em 2004.
} 
contraste entre o rural e o urbano enquanto espaços simbolizados, bem como pela mobilidade do sujeito: trata-se de um sujeito que se desloca de um ambiente rural para um ambiente urbano. Veremos, no decorrer do trabalho, como a mobilidade geográfica implica em uma reorientação simbólica (cf. PAYER, 1996): as letras de músicas sertanejas são textualizações em que isto se marca discursivamente.

O recorte produzido pela presente pesquisa, em que o locutor sertanejo diz de seu amor por sua mãe, e dela por ele, relaciona-se à produção do contraste entre o rural e o urbano, como espaços distintos, separados: nota-se que se fala a partir de um presente em que a mãe está ausente, está distante no tempo e/ou no espaço. Através das canções, um locutor sertanejo demonstra seu amor por sua mãe, amor enaltecido devido a fatores como a separação. A separação/ saudade da terra de origem (espaço rural) é, pois, também uma separação/ saudade da mãe - e vice-versa.

Pensando no discurso como algo determinado pelas condições de produção, começamos por perguntar quais seriam as condições desse discurso do amor filial nas músicas sertanejas. Os efeitos de sentido das letras que vamos analisar estão ligados à história da música sertaneja, bem como à produção de um sujeito que, no espaço urbano, diz de sua origem rural. A música sertaneja é hoje uma música urbana, voltada para um público de consumidores, produzida a partir das relações de mercado. Apesar destas condições de produção, ela continua se significando como "sertaneja", o que nos coloca a questão da contradição constitutiva dos/nos processos históricos. No caso da música sertaneja, trata-se de compreender a significação da migração do rural para o urbano, e, nela, os movimentos de sentido / de identificação possíveis para o sujeito.

Através de uma primeira análise das letras, podemos apontar algumas questões que procuraremos responder para compreender o funcionamento simultaneamente de um discurso de amor filial e um discurso sobre o amor materno: Como funciona o discurso de amor e o discurso sobre o amor nas letras de música sertaneja? Como se subjetiva o locutor sertanejo nessas letras? Podemos dizer que cantar o amor materno faz parte do modo de subjetivação do locutor sertanejo? Quais as marcas discursivas que apontam para esse modo de subjetivação? Como a mãe é significada nesse discurso?

Para responder a essas perguntas, primeiramente falaremos sobre a música sertaneja e a cultura caipira, da qual é proveniente, a fim de que possamos compreender as condições de produção das músicas do corpus e relacioná-las à significação da figura materna, o nosso foco. 


\section{Música sertaneja}

De acordo com Caldas (1999), a música sertaneja em seus primórdios tinha uma função social, ela estava ligada às festas religiosas e profanas, além do trabalho. Como mediadora das relações sociais nas comunidades caipiras, a música sertaneja (música caipira) não era um produto da indústria fonográfica, as canções nem tinham autores definidos e o tema de suas letras era o cotidiano do homem rural.

Essa prática da música como um ritual nas relações da sociedade caipira começaria a diminuir a partir da primeira gravação do estilo musical em disco, em 1929. Desse momento em diante, a música sofreria transformações em função da própria mercantilização e da urbanização do país, sendo voltada para um público consumidor que na atualidade é, em sua grande maioria, urbano. Dessa forma, a música sertaneja foi se modificando pouco a pouco até se tornar essa música que conhecemos hoje.

É importante afirmar que compreendemos esta questão em termos dos processos discursivos em jogo, o que significa uma postura crítica em relação a perceber uma evolução cronológica na música sertaneja em que um estilo tradicional seria substituído por outro mais moderno. A questão é mais complexa e se observa uma coexistência e o entrecruzamento de discursividades do urbano e do rural, embora aconteça a superação de um estilo por outro em termos de grande mídia. É claro que, se a tendência é o sertanejo universitário, como ocorre na atualidade, o sertanejo raiz perde espaço, pois os novos músicos buscam seguir o estilo mais requisitado. Porém, a música sertaneja raiz, assim como outros estilos sertanejos que se diferenciam do universitário, continua a ter seus seguidores, mesmo afastada da grande mídia.

Caldas (1999), por exemplo, considera que por volta de 1970 ocorre uma divisão entre música sertaneja raiz e música sertaneja moderna. Essa divisão se dá devido aos novos rumos que a música sertaneja havia tomado, sofrendo influência de outros estilos musicais, e em suas condições de produção, pela própria modernização do país. Zan (1995) diz que a modernização da música sertaneja aconteceu também devido a modernização da indústria fonográfica, que passou a produzir melhor e com mais sofisticação o trabalho dos artistas da época, deixando de lado elementos de rusticidade, o que contribuiu por desvincular a música sertaneja de seu meio rural, ainda que esses mesmos elementos tenham sido usados para conquistar o público das cidades, formado, inclusive, por migrantes do campo. Isso em uma época de intensa migração da população rural em direção às cidades, de modo que o Brasil passava a constituir a imagem de país urbano/ urbanizado. 
Além da urbanização e modernização da indústria fonográfica, as comunidades caipiras se tornaram raras, o que também contribuiu para um declínio da temática rural ou para a sua ressignificação. Vejamos um pouco como se constituem essas comunidades, para que compreendamos o seu papel na produção de música sertaneja, papel este que se reflete ainda nas canções atuais, mesmo que de maneira bastante tímida.

\title{
As comunidades caipiras
}

De acordo com Ribeiro (1995), as comunidades caipiras se formaram pelos posseiros e agregados, que não tinham condições de legalizar as terras onde viviam. Esses posseiros e agregados tornaram-se responsáveis pela formação dos bairros rurais com formas de trabalho e de lazer próprias, como os mutirões. Hoje em dia, comunidades caipiras como estas, que tinham pouca relação com o mercado, são raras.

Setubal (2005) frisa que a cultura caipira não é homogênea, há variações entre as comunidades. Há, porém, traços semelhantes entre elas, e são estes traços que nos possibilitam caracterizar as sociedades caipiras.

Mesmo sendo raras na atualidade, as comunidades caipiras estabeleceram costumes que refletem nas populações do interior, mais especificamente na região sudeste e centro-oeste. Com a urbanização do país, muito dos seus traços estão hoje ressignificados, é o que nos afirma Setubal (idem):

\begin{abstract}
a permanência dessa cultura caipira ou de traços determinantes dela, [...] hoje [...] está transformada e ressignificada. No entanto, ela continua, a nosso ver, como um exemplo de resistência, talvez na maior parte das vezes, de forma inconsciente, pois, apesar de toda a marginalização sofrida, especialmente por parte dos meios de comunicação e da elite da sociedade, essa cultura permanece na alma e concretamente em festas e tradições mantidas pelo povo. Essa concretude se dá pelos aspectos [...] que ainda fazem parte do imaginário de alguns e do dia-a-dia de outros: terra e natureza; linguagem; modo de vida, costumes e comidas; o coletivo e a generosidade; a religiosidade, o tempo, o lazer e as festas (p.131).
\end{abstract}

Como podemos ver, a autora defende que a manutenção dos costumes, mesmo que de forma transformada, é uma forma de resistência do sujeito caipira, como sujeito que, ao se significar e ser significado, significa às margens de uma sociedade que se afirma como urbana (não-caipira). Acreditamos que a música sertaneja, mesmo a moderna, é uma dessas formas de resistência, pois afirma essa diferença para com o imaginário de pertencimento ao urbano e se mostra, ao mesmo tempo, como parte integrante do meio urbano. 
Entender essa relação que a música sertaneja tem com o rural e com o urbano, bem como com a cultura caipira, implica considerar que as letras em análise não são textos fechados em si próprios e nem transparentes, elas tem sua historicidade, ou seja, uma relação com a exterioridade. A historicidade é constitutiva dessas letras e, dessa forma, "se se pode pensar uma temporalidade, essa temporalidade é uma temporalidade interna, ou melhor, uma relação com a exterioridade tal como ela se inscreve no próprio texto e não como algo lá fora, refletido nele" (ORLANDI, 2007, p.55). É nesse sentido que o texto é pensado como algo não transparente, mas algo opaco, que tem uma materialidade linguística.

É pensando na historicidade do texto, no seu modo de produzir sentidos, que Orlandi (2007) conclui que o texto é um material linguístico-discursivo, atravessado por várias formações discursivas. Podemos então dizer que as letras em questão são atravessadas, entre outras, por formações discursivas que remetem a um modo de vida caipira ou rural, ainda que, nas mais modernas, não estejam evidentes.

Considerando então que essa discursividade atravessa as canções do corpus, e tendo como foco o discurso sobre o amor de mãe, convém falarmos um pouco da significação da figura materna na família de cultura caipira, a fim de que possamos compreender a relação mãe/filho nessa sociedade rural.

\section{A mãe na família caipira}

Segundo Brandão, o trabalho nas comunidades caipiras "é essencialmente um trabalho em família" (1983, p. 68); assim sendo, podemos considerar que há bastante proximidade entre os membros de uma família caipira, juntos até mesmo no trabalho. A mãe, como cuidadora do lar, tem um papel essencial no trabalho, pois está bastante presente na casa e no quintal, dois dos lugares que Brandão (idem) considera como principais locais do trabalho caipira. Os filhos, que desde pequenos já ajudam nos serviços domésticos, crescem nesse ambiente, onde está o amparo de sua mãe.

Chega uma hora, porém, que o filho cresce e a separação é inevitável. As letras que estamos analisando abordam essa separação. No caso do sujeito proveniente de uma cultura caipira, a separação muitas vezes se dá pela migração para uma grande cidade, lugar onde o caipira busca melhores condições de vida. Na distância, a saudade do lar e da mãe não demora a incomodar. É esse incômodo e essa distância que deflagram o falar sobre/com a mãe, de modo que no lugar da distância/ausência incômoda se 
coloque o "amor", na significação de um sujeito (o locutor sertanejo) que fala desse amor.

Vejamos então, na sequência, através de alguns recortes, como é produzida essa afetividade do sujeito filho.

\section{A significação da figura materna no corpus sob o discurso de/sobre amor: subjetividade, estereótipo, contradição e desejo de completude.}

Segundo Orlandi (1999), no discurso sobre o amor, relata-se o amor, fala-se sobre ela ou ele (amada ou amado), e mesmo quando se refere ao tu (você), pode ainda ser um discurso sobre o amor, se o locutor dialoga com seu próprio texto ao invés de dialogar com seu interlocutor. No discurso de amor, segundo a autora, tem-se uma situação enunciativa própria, não se distingue o sujeito do enunciado e o sujeito da enunciação, eles são os mesmos; além do mais, o sujeito se significa pelo outro, e por isso a interlocução com o tu é direta e essencial. Vejamos alguns recortes do nosso corpus em que aparece o discurso de amor:

\section{"Em $\underline{\text { meu }}$ passo teu cuidado}

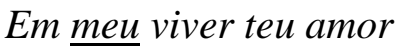

Em minha alegria canta

E chora com minha dor"

"Mãe, hoje eu precisei de você

Eu não sabia o que fazer

Me vi de mãos atadas"

Os pronomes grifados marcam o lugar de um sujeito da enunciação, que se significa como filho, ao dizer do seu amor por sua mãe. Ao lado dos pronomes da $1^{\text {a }}$. pessoa, marca-se a interlocução com esse amor de mãe: "teu amor", "teu cuidado", "Mãe", "precisei de você".

Segundo Orlandi (1990), o discurso de amor é o espaço no qual o sujeito elabora sua sensação de amor, é o momento em que o sujeito torna-se protagonista do discurso, e por isso pode ser considerado um discurso privilegiado com relação à subjetividade, que "não é apenas constitutiva, ela é mostrada" (ORLANDI, 1990, p. 84). Nesse caso, podemos pensar que, nas músicas que estamos analisando, o locutor sertanejo se 
exprime pela sua singularidade, pois ele não fala apenas das mães em geral, mas da sua própria mãe.

Pensando essa distinção, podemos considerar que há nas músicas em análise tanto um discurso sobre o amor (sobre o amor de mãe) como um discurso de amor (do filho). Isso varia conforme a música, podendo uma mesma música ser atravessada pelos dois modos de enunciação. Ora o locutor sertanejo fala diretamente com sua mãe, mostrando o amor que sente por ela, ora fala sobre ela com outro interlocutor, demonstrando que a sua mãe ou as mães em geral têm um grande amor por seus filhos. Vejamos alguns recortes que mostram o discurso sobre o amor materno:

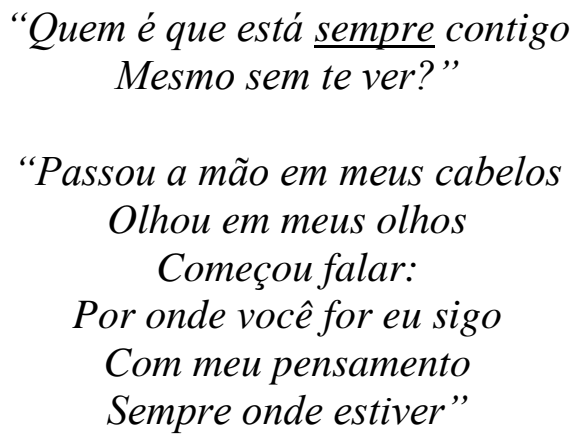

Note que, nesses recortes, o sujeito não fala diretamente com a mãe. Mas a descrição do amor materno, incondicional e atemporal, funciona aí como demonstração de amor, isto é, faz parte também da mesma "subjetividade mostrada" - segundo as palavras de Orlandi a respeito do discurso amoroso.

Acreditamos que o discurso sobre o amor também apresenta em seu funcionamento semelhanças com o discurso de amor, e mesmo quando o locutor sertanejo fala sobre sua mãe, ele quer demonstrar seu amor de filho e evidenciar o quanto sua mãe o ama, já que exalta esse amor materno. Por isso grifamos a palavra "sempre", para mostrar outra característica do discurso de amor, que aí se faz presente no discurso sobre o amor: a atemporalidade. O discurso de amor não só é atemporal, mas também repetitivo, significando-se pelos gestos cotidianos, pelos rituais circunstanciais do dia-a-dia, sem isso ele não poderia expressar sua atemporalidade. É pela repetição que o sujeito garante a sua duração, ou melhor, seu sentimento de duração. Essa repetição não é retorno, mas descontinuidade contraditória que se faz pela ruptura e pelo silêncio (ORLANDI, 1990).

Outra característica do discurso de amor é a contradição. Sem dúvida, ela é um dos efeitos mais marcantes desse discurso, e pode aparecer nas formas cristalizadas 
(estereotipadas) de se demonstrar o amor. Orlandi (1990) faz uma análise da fórmula eu-te-amo, a mais comum, dizendo que ela pode tanto inviabilizar o amor como ser algo que diz tudo, melhor dizendo, ela não é capaz de exprimir tudo que o sujeito sente e quer falar, mas por outro lado pode ser a forma do sujeito dizer tudo que sente em menos palavras, como se a fórmula contivesse todo sentido do amor. Podemos observar fórmulas como essa no discurso de/sobre o amor instaurado nas canções, que também jogam com essa contradição do tudo e do nada. É o que podemos observar nesse recorte:

"Mãe, tão puro amor de mãe Que às vezes não me vêm palavras pra expressar Mãe, pra ti conjugo o verbo amar"

Através da fórmula "pra ti conjugo o verbo amar", o locutor sertanejo exprime todo seu amor, mas ao mesmo tempo não lhe "vêm palavras pra expressar" esse amor.

Ao dizer seu amor através de fórmulas como eu-te-amo, "o sujeito está trabalhando sua finitude e seu desejo de eternidade" (ORLANDI, 1990, p. 92). No discurso de amor, a ilusão que o sujeito tem de ser a origem do seu dizer é ainda mais forte e se dá na relação do sujeito com a duração de sua subjetividade, é nessa relação que ele afirma sua eternidade, sua completude, sua singularidade. O dizer aparece como se fosse a primeira vez e para sempre. Novamente aparece a contradição, o aqui manifestando o momento da enunciação e o sempre manifestando a duração do dizer de amor, um paradoxo entre o instante imediato e o eterno.

Orlandi (1990) diz que as fórmulas de amor podem significar de diferentes maneiras, como, por exemplo, comprometimento perante a lei do casamento. No nosso caso, pensamos que ela traz uma ideia de gratidão, de reconhecimento do amor demonstrado pela mãe e todo seu esforço para ver o filho feliz.

Outro fator interessante do discurso de amor, que também se dá na contradição e que vai aparecer na descrição da dedicação do amor materno, é a absolutização. Segundo Orlandi (1990), a absolutização é um componente da relação complexa entre unidade e dispersão, inerente ao tenso processo de subjetivação do sujeito. Nesse movimento de identidade, o sujeito atravessa e é atravessado por várias formações discursivas, o que atesta sua incompletude, sua significação dependente da historicidade; não há um sujeito em si, onipotente. Mas, por outro lado, o apagamento dessa significação pela exterioridade, pelo pré-construído, faz com que o sujeito 
alimente seu desejo de completude, ele acredita ser singular, e essa singularidade no discurso de amor se dá através do outro, do "vínculo com o outro, na remissão à formação discursiva (ORLANDI, 1990, p 85)". É nesse sentido que o sujeito filho se significa pela mãe e, assim sendo, ambos aparecem como se fossem um, em uma relação de interdependência. Vejamos um exemplo:

\section{"Te leva você junto ao peito \\ Mesmo antes de nascer \\ Sorri com tua alegria \\ Chora a sua solidão”}

Podemos ver que o recorte mostra mãe e filho como dois sujeitos inseparáveis, indissociáveis, a mãe leva o filho "junto ao peito" mesmo antes do nascimento e seu estado emocional depende do estado emocional do filho.

O discurso de amor mais uma vez se dá na contradição, porque, no jogo entre unidade e dispersão, o sujeito, ao subjetivar-se em sua singularidade, acaba se desgarrando de si mesmo. "Nesse desgarramento, amar é deixar-se dizer pelo discurso do outro. Ser significado, (significar-se) pela fala do outro" (ORLANDI, 1990, p. 86). Por isso dizemos que o filho se significa pela mãe, é demonstrando o amor dela que ele demonstra o seu próprio amor. Veremos isso novamente mais à frente.

Apesar da contradição ser uma característica do discurso de amor, nesse recorte que estamos analisando, ela aparece no discurso sobre o amor de mãe. Isso nos mostra que os dois tipos de discurso se confundem nas canções do corpus, ou melhor, estão entrelaçados.

Podemos notar que o locutor sertanejo se desgarra de si e se significa pelo discurso do outro (a sua mãe). Isso acontece porque há um vínculo entre mãe e filho que permite essa apropriação do discurso do outro.

Pensamos que o discurso sobre o amor, embora menos subjetivo do que o de amor, não chega a ser um discurso marcado pelo distanciamento com relação àquilo do que se fala, aqui, no caso, o amor materno. Isso porque, partindo do filho, não se pode dizer que ele tem um olhar objetivo a respeito da figura materna. Mesmo que esse olhar se dê através de um estereótipo, que vai aparecer também na forma de demonstrar o amor, como já vimos, ao mesmo tempo, pelo vínculo que tem com a mãe, vai expressar seu amor de forma marcadamente subjetiva, e aí se aplicam as marcas do discurso de amor que discutimos neste texto. 
Ao falar da mãe, o locutor sertanejo, na sua posição de sujeito filho, mostra tanto seu desejo de completude como o desejo de completude da mãe. A mãe, inclusive, aparece como um sujeito ainda mais dotado dessa completude ilusória, seu amor é incondicional e eterno. Esse é um ponto importante para entendermos a significação da figura materna nessa sua formulação específica nas letras de música sertaneja.

$\mathrm{Na}$ sequência, mostraremos a relação desse discurso amoroso com a exterioridade, o que nos possibilita compreender como nesse discurso (se) produz sentido, dada a relação específica deste com a historicidade. Ou seja, as questões de sentido aqui apontadas remetem à significação desse sujeito amoroso enquanto "sujeito caipira" (locutor sertanejo), em suas relações com as discursividades do urbano e do rural, como meios/ culturas distintas, em suas especificidades.

\section{O locutor sertanejo separado de sua mãe: um sujeito entre o rural e o urbano}

Essa relação do locutor sertanejo com as discursividades do urbano e do rural é importante para entendermos o discurso amoroso do filho com relação à separação, marcada no discurso por um distanciamento físico que gera saudade, dor e sofrimento. A distância geográfica e temporal que afasta o locutor sertanejo de sua mãe significa a e ao mesmo tempo é significado pela - mudança de um ambiente rural para um ambiente urbano, em que a cidade é frequentemente o lugar de destino do sujeito que deixa o campo. Sendo o campo e a cidade constituídos por discursividades específicas, a mobilidade do sujeito filho do rural para o urbano interfere na sua constituição enquanto sujeito caipira, e consequentemente na significação que ele faz da figura materna.

Payer (1996) nos diz que "a mobilidade geográfica dos indivíduos requer (e produz) enquanto condições de produção dos sentidos, uma alteração também na orientação simbólica, quanto às imagens que o sujeito faz de si, do outro, dos objetos de referência" (p. 96). Assim sendo, podemos dizer que o discurso de amor do filho na cidade ganha uma especificidade marcada por essa alteração na orientação simbólica, como nos diz a autora. Deixando sua mãe no campo, o discurso de amor do filho se intensifica, pois ela não está mais junto dele. E, nesse sentido, o discurso volta-se para o passado, constituindo-se em lamento da ausência do amor materno no presente. Vejamos:

\footnotetext{
"Eu bem queria continuar ali

Mas o destino quis me contrariar

E o olhar de minha mãe na porta

Eu deixei chorando a me abençoar"
} 
Esse recorte mostra o desejo do sujeito de estar junto da mãe. Essa vontade permanece mesmo na separação, por isso o discurso se volta para o passado, fazendo com que o sujeito recorde os momentos vividos com a mãe no tempo em que ela estava junto dele.

O verso "e o olhar de minha mãe na porta" do recorte acima merece uma atenção especial, pelo modo específico de significar a separação do filho em relação à sua mãe e, ao mesmo tempo, o amor que os une. É através de uma metonímia que o filho diz sobre o momento de despedida/ de separação. Dizer que deixa o olhar da mãe na porta é dizer que deixa a mãe na porta, mas é também mais do que isso. Não se disse dos braços ou do colo, partes também significativas de um corpo da mãe, mas do olhar, dos olhos, dos quais dizemos serem o espelho da alma.

Esse sintagma mostra mais uma vez a subjetivação do locutor sertanejo, que afirma o seu próprio olhar, através do olhar da mãe. A plasticidade da materialidade linguística que constitui o verso produz efeitos de sentido que significam a relação entre mãe e filho em sua intensidade. Verifica-se, com essa estrutura sintática, a produção de uma intercambialidade entre o sujeito e o objeto do "olhar" e do "deixar", nos efeitos de sentido que significam simultaneamente o amor de filho e o amor de mãe. Assim, o verso que marca o momento da despedida, mostra o sujeito filho constituindo-se através do olhar (d)a mãe: o falar dela é falar de si mesmo.

A remissão à "porta" também é bastante significativa nesse verso, ela marca o ponto de despedida, estabelecendo uma divisão entre os dois espaços simbólicos do locutor sertanejo: o seu lugar de origem (o campo, pequena cidade do interior), seu lar familiar, que figura no enunciado como o passado; e o lugar de destino, menos familiar ou desconhecido (grande cidade), e que já se configura como o presente do enunciado, o lugar da enunciação.

A presença da mãe na porta mostra mais uma vez a descrição, por parte do filho, de uma mãe dedicada, que quer estar sempre presente, ela não pode ir com ele, mas vai até onde pode, no limite, que é porta. Não podendo estar fisicamente junto do filho, só resta à mãe acompanhá-lo no pensamento, rezar por ele, pedir a Deus proteção e abençoá-lo: esse discurso amoroso é atravessado também por uma discursividade de caráter religioso. 


\title{
Santificação da mãe e sua associação ao discurso religioso
}

O discurso religioso é muito presente, expressando-se de modos diferentes. Encontramos no corpus a aproximação da mãe com a própria mãe de Deus (Nossa Senhora). Temos na adoração ou na benção duas formas de referir a relação do filho com a mãe como uma relação que passa pelo sagrado. Vejamos:

\author{
"É o nome que na vida eu mais adoro \\ Sendo ela a razão do meu vivê \\ É mesmo que adorá Nossa Senhora \\ Que está no céu para sempre nos valê" \\ "Fique certa, Deus também guardou \\ Você no coração" \\ "Mãe! Deus te acompanhe mãe" \\ "Eu quero beijar tua mão \\ A bênção, oh mãe querida \\ Pedindo a Deus proteção \\ E muitos ano de vida."
}

Esses recortes nos mostram que o amor entre mãe/filho realiza-se no cotidiano através de rituais instituídos por elementos de caráter religioso, que afirmam a religiosidade como parte constitutiva das relações familiares nesse âmbito discursivo. Os signos religiosos, como a benção, estabelecem uma ordem discursiva na relação entre mãe e filho: a mãe é aquela que pode abençoar, enquanto o filho é aquele que deve pedir essa benção e obedecer, seguir conselhos de sua mãe, respeitá-la.

E é nesse contexto ainda que o filho também pede a Deus proteção por sua mãe, reza por ela. A demonstração do amor apoiada no discurso religioso configura-se como algo que serve para intensificar esse amor, além de mostrar que o sujeito filho cumpre seu dever de bom filho dentro da ordem discursiva estabelecida.

Se a mãe é caracterizada como uma santa, como aquela que pode abençoar, e o filho caracterizado como o que deve a ela se submeter, respeitá-la e ouvir seus conselhos, o não cumprimento dessa ordem discursiva é tido como pecado, o que no discurso religioso pode ser considerado um tipo de transgressão, a "quebra das regras do jogo" (Orlandi, 2011, p. 254). A regra quebrada aí seria o quarto mandamento: Honrar pai e mãe. Vejamos alguns recortes que falam sobre isso: 
"Desprezá ela e não ouvi os seus conselho

Esse pecado eu não levo quando eu morrê"”

Se, no recorte acima, o sujeito revela sua fidelidade à mãe, sua obediência, neste outro o filho confessa sua culpa e mostra arrependimento:

\section{"Mãe, hoje aqui sozinho eu rezei \\ Aqui no meu cantinho eu chorei E chorando fiz uma jura}

\section{Juro que a partir de hoje eu vou fazer meu tempo \\ Vou ficar mais perto do teu sentimento \\ Vou ficar mais perto, mãe, do teu amor"}

O trecho acima transcrito nos mostra o reconhecimento do filho quanto a uma falta sua em relação ao amor de mãe, o que seria uma ingratidão por parte dele. A falta de amor do filho para com a mãe significa que esse sujeito não estaria apenas distante da mãe, mas também, de algum modo, distante do amor da mãe. Dessa forma, o locutor faz uma jura, que é a de "não esquecer"; o locutor sertanejo quer ficar perto do amor de sua mãe, o que não significa aproximação física, mas uma aproximação pela lembrança do sentimento amoroso. A separação entre mãe e filho está, inclusive, intensificada, como podemos notar em "hoje aqui sozinho" e "aqui no meu cantinho" - trechos em que o locutor sertanejo marca o lugar de onde fala (o espaço urbano) como lugar de isolamento/ separação, dada a relação com uma estrutura familiar (no espaço rural), que o acolhia e da qual estaria, no presente da enunciação, desmembrado.

O discurso religioso parece se manifestar mais intensamente na separação também. Embora a religiosidade não seja característica somente das comunidades caipiras, podemos considerar uma marca da discursividade rural, pela inscrição do "caipira" em uma tradição católica popular. A relação com o religioso está bastante presente nas canções sertanejas, considerando-se que as primeiras músicas tinham mesmo funções rituais no cotidiano da sociedade caipira, funcionando como modo de permanência da/na tradição católica. Verifica-se, porém, que o discurso religioso ecoa mesmo nas canções mais modernas (não raiz). Assim sendo, quando o tema é a própria religião ou a família, esse discurso aparece de forma intensa, mostrando que o locutor sertanejo é um sujeito religioso, proveniente de uma sociedade que valoriza ao mesmo tempo a religião e a família. 


\section{As marcas de um discurso caipira}

A variante linguística que, nas canções analisadas, evidencia a identidade caipira, encontra-se fortemente presente nas duas canções mais antigas do corpus ${ }^{3}$, que são da década de 60 e 70. Esse locutor sertanejo fala a partir de uma linguagem que, de uma perspectiva urbana, seria caracterizada por "desvios gramaticais" como a troca do L pelo R, como observamos em "farta", redução de ditongo ("lutô"), eliminação de redundância do plural ("seus filho cresce”) entre outros. Vejamos alguns trechos:

\section{"Minha mãe, como faz farta tua vida em meu vivê" \\ "Que lutô tanto e por nós sofreu calada Mas é bem poucos que sabe reconhecê"}

Além da variante linguística empregada, podemos observar outras marcas de um discurso caipira, como a remissão ao interior (pequena cidade):

\section{"E sempre ao lado do meu pai Da pequena cidade ela jamais saiu"}

A permanência da mãe em sua pequena cidade mostra uma grande característica caipira: o amor pela terra, pelo seu lugar de origem, o qual o caipira não costuma abandonar, a não ser que as circunstâncias o obriguem.

A ocorrência do dialeto caipira nas canções mais antigas pode, em parte, indicar um processo cronológico em que a música sertaneja passa a se urbanizar, deslocando-se dessa forte marca de significação do sujeito rural, que é a "fala caipira". Consideramos, porém, no presente trabalho, que as canções sertanejas abrangem a divisão entre sertanejo moderno e sertanejo raiz, divisão em que se pode conceber modos diferentes de expressão de um locutor sertanejo. Na realidade, trata-se de perceber aí a possibilidade de um determinado sujeito, na produção poética, de se identificar ou não pela "origem popular", através de uma fala marcada como tal (não escolarizada).

Essa questão do deslocamento do sujeito caipira de sua terra de origem (tema muito abordado em músicas sertanejas), bem como a questão da língua empregada, tem, portanto, uma relação estreita com a urbanização do país. A distinção entre rural e urbano, enquanto dois espaços contrastantes, distantes, é uma questão que toca

\footnotetext{
${ }^{3}$ As letras dessas canções foram transcritas de acordo com a linguagem empregada pelos artistas que as interpretam, observando as gravações mencionadas na quarta nota de rodapé.
} 
diretamente o "cantar o amor da mãe" pelo locutor sertanejo, já que esse cantar tem tudo a ver com a separação do filho, que vai para a cidade grande.

Pensando nas duas canções que utilizam o dialeto caipira, poderíamos dizer que, a partir de uma discursividade caipira, o locutor sertanejo marca sua posição sujeito (identidade caipira), inclusive através da variante linguística empregada, que lhe é significante. Falar o dialeto caipira é mostrar-se parte de uma sociedade caipira, é afirmar uma identidade própria através dessa língua que o constitui como sujeito caipira. Essas canções se mostram então como um lugar de fala desse sujeito caipira, onde a ocorrência da variante linguística não é estranha, mas, ao contrário, é o "lugar correto".

\section{Considerações finais}

Primeiramente, em relação à figura da mãe, a exaltação do amor materno mostra que nesse conjunto de textos se faz presente a idealização da figura materna. Mais do que expressar seu amor pela sua mãe, o locutor sertanejo é levado a falar "a mãe" de modo a reforçar os estereótipos sobre a figura materna presentes na sociedade - no sentido da imagem de uma "abnegação materna", pela sua caracterização como alguém extremamente amável, compreensiva, carinhosa, dedicada, cuidadosa e principalmente que sofre por causa do filho e pelo filho. Contudo, vimos que, no discurso de amor, o estereótipo significa mais do que uma forma cristalizada: "Pensamos que só uma redução drasticamente pragmática se beneficia da visão do estereótipo em sua fixidez. Discursivamente, ele pode ser visto como um lugar de manifestação do dizer para ultrapassar essa fixidez mesma que ele aponta" (Orlandi, 1999, p. 80).

Pudemos ver que o discurso amoroso instaurado nas canções é um discurso marcadamente subjetivo, no qual o locutor sertanejo se significa pela intensidade de seu amor, gratidão e carinho pela mãe. Essa subjetividade é constitutiva do sujeito, ela revela seu desejo de completude e identidade. A separação, como vimos, é o que impulsiona o locutor sertanejo, enquanto sujeito filho, a exprimir seu amor de forma intensa.

Deve-se considerar ainda que, no plano simbólico, a urbanização tende a diminuir a distância entre rural e urbano. A tecnologia chega ao campo fazendo com que este assimile elementos do urbano, provocando uma alteração na orientação simbólica para o sujeito caipira, algo que acontece também na migração do campo para 
a cidade, como nos fala Payer (1996). O contato com discursividades urbanas por parte do sujeito caipira se dá, portanto, não apenas na cidade, mas no próprio campo.

É de se notar que, muito embora o processo de urbanização seja real e se apresente como parte das condições de produção da música, a nomeação "música sertaneja", bem como a adjetivação "sertanejo" em outros sintagmas, de alguma forma, mantém-se atual. O crescimento intenso da música sertaneja e a hegemonia de um modo de vida, o urbano, poderiam explicar, por outro lado, a diminuição da ocorrência do tema do amor entre filho e mãe $e^{4}$.

Voltando ao discurso amoroso, e finalizando nossa reflexão, queremos salientar mais uma vez que o discurso de amor de filho e o discurso sobre o amor de mãe se constituem nas canções de forma entrelaçada, sem que haja uma distinção acentuada. $\mathrm{O}$ discurso religioso encontra-se também aí presente, associado ao discurso amoroso, atravessando-o, e marcando essa relação do sujeito com uma tradição popular, ao mesmo tempo familiar e religiosa. Percebemos a importância de compreender a especificidade do locutor sertanejo como lugar do qual se fala, entre as discursividades urbana e rural: este é um lugar enunciativo a partir do qual se fala do campo e da cultura caipira (ou seja, do espaço rural), situando-se já em um lugar outro, a cidade, o espaço urbano. $\mathrm{O}$ ambiente rural e seus elementos constitui o sujeito, mesmo que se apresentem enquanto elementos de um outro tempo e/ ou de um outro espaço. A representação nas letras desse distanciamento, ela mesma, produz-se como marca de uma identificação profunda, afetiva, de modo que, com a música sertaneja, o sujeito pode mostrar de onde jamais saiu.

\section{Referências bibliográficas}

Brandão, C. R. 1983. Os caipiras de São Paulo. São Paulo: Brasiliense.

Caldas, W. 1999. O que é música sertaneja. São Paulo: Brasiliense.

Guimarães, E. 2010. Andorinha, andorinha. In Revista Ecos. Ed. no 009 [s. 1]: [s. n], p. 197-207, jun.

\footnotetext{
${ }^{4}$ Esta reflexão se baseia no fato de que a música mais recente do corpus é de 2004, e que desse momento em diante não teria surgido na grande mídia uma música com a mesma temática abordada neste trabalho. É importamos relacionar isso com o mercado fonográfico e com a grande mídia, que acabam ditando quais os temas a serem abordados pela música sertaneja na atualidade.
} 
Orlandi, E. P. 1990. Palavra de amor. In Cad. Est. Ling.. Campinas: [s. n], P. 75-95, jul./dez.

2007. Interpretação: autoria, leitura e efeitos do trabalho simbólico. $5^{\text {a }}$ Edição. Campinas: Pontes.

Campinas: Pontes.

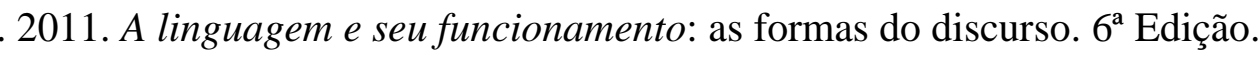

. (org.) 2001. Cidade atravessada. Campinas: Pontes.

. (org.) 2004. Cidade dos sentidos. Campinas: Pontes.

Payer, M. O. 1992. Retrospecção e estereotipia: imagens urbanas sobre o campo. In

Revista Rua. Campinas: [s. n], n.2, p. 83-101.

Ribeiro, D. 1995. O povo brasileiro: a formação e o sentido do Brasil. São Paulo: Cia das Letras.

Setubal, M. A. 2005. Vivências caipiras: pluralidade cultural e diferentes temporalidades na terra paulista. São Paulo: CENPEC / Imprensa Oficial do

Estado de São Paulo, 2005.

Zan, José Roberto. 1995. Da roça a Nashville. In. Revista Rua. Campinas: [s. n], n.1, p. 113-136.

\section{Anexos}

Segue abaixo as letras e seus respectivos links para audição. Sendo links do Youtube, as músicas podem ser ouvidas acompanhadas de imagens ou de mensagens. Alertamos o leitor para o fato de que essas imagens e mensagens não foram analisadas.

Mamãe, Mamãe, Mamãe - Gravada por Tonico e Tinoco (1964)

Link para ouvir a música: https://www.youtube.com/watch?v=hwfwaM9YXdo

$$
\begin{gathered}
\text { Puremente eu trago guardado } \\
\text { Na parma da minha mão } \\
\text { É o nome de mãe gravado } \\
\text { No fundo do coração }
\end{gathered}
$$

Mamãe, mamãe, mamãe, como eu gosto de você

Minha mãe, como faz farta tua vida em meu vivê

\footnotetext{
Eu quero beijar tua mão

A bênção, oh mãe querida

Pedindo a Deus proteção

E muitos ano de vida

Em meu passo teu cuidado

Em meu viver teu amor
} 
Em minha alegria canta

E chora com minha dor

Mãe amorosa - Gravada por Abel \& Caim (1973)

Link para ouvir a música: https://www.youtube.com/watch?v=SeAW5jbCQxY

Entre as palavras do mundo que tanto eu amo na vida

O santo nome de mãe é a palavra mais querida

Por isso esta canção será minha mensageira

Para levar todo afeto a você, mãe brasileira

Você já sabe qual é o nome que eu adoro

Que todos nós têm orgulho em dizê

É o nome de uma imagem tão querida

E que nunca nós devemos esquecê

É o nome da nossa velha mãezinha

É um tesoro pra quem sabe compreendê

Que lutô tanto e por nós sofreu calada

Mas é bem poucos que sabe reconhecê

Quando os filho estão todos pequenino As pobre mãe se cansa de padecê

Pra não dexar falta nada pros filhinhos

Elas trabalha muitas vezes sem podê

Se ela é rica ela tem todos conforto

Mai se ela é pobre muitas veis tem que sofrê

Elas passa os trabalho e não reclama

E tem orgulho em vê os seus filho crescer

E depois que seus filho estão criado

Vem o destino logo para interrompê

Um se casa e outros vão para longe

Sempre deixando seu coração a doê

Um coração que vive cheio de saudade

De quem foi embora e demora pra se vê

Entre soluço ela se fecha num quarto

E seu consolo é suas lagrimas corrê

Como é bonito chamá o nome de mãe

E satisfeita ela vem nos atendê

É o nome que na vida eu mais adoro

Sendo ela a razão do meu vivê

É mesmo que adorá nossa senhora

Que está no céu para sempre nos valê

Desprezá ela e não ouvi os seus conselho

Esse pecado eu não levo quando eu morrê

No Dia Em Que Eu Saí de Casa - Gravada por Zezé Di Camargo \& Luciano (1994) Link para ouvir a música: https://www.youtube.com/watch?v=rsXJ6a5qBhA

No dia em que eu saí de casa

Minha mãe me disse:

Filho, vem cá!

Passou a mão em meus cabelos

Olhou em meus olhos

Começou falar 
Por onde você for eu sigo

Com meu pensamento

Sempre onde estiver

Em minhas orações

Eu vou pedir a Deus

Que ilumine os passos seus

Eu sei que ela nunca compreendeu

Os meus motivos de sair de lá

Mas ela sabe que depois que cresce

$\mathrm{O}$ filho vira passarinho e quer voar

Eu bem queria continuar ali

Mas o destino quis me contrariar

E o olhar de minha mãe na porta

Eu deixei chorando a me abençoar

A minha mãe naquele dia

Me falou do mundo como ele é

Parece que ela conhecia

Cada pedra que eu iria por o pé

E sempre ao lado do meu pai

Da pequena cidade ela jamais saiu

Ela me disse assim:

Meu filho, vá com Deus

Que este mundo inteiro é seu

Mãe - Gravada por Lucas \& Luan (1997)

Link para ouvir a música: https://www.youtube.com/watch?v=D_MZW42utYM

Quem é que está sempre contigo

Mesmo sem te ver?

Te leva você junto ao peito

Mesmo antes de nascer?

Sorri com tua alegria

Chora a sua solidão

Quem foi que te guardou pra sempre

Em seu coração?

Te leva no seu pensamento

Onde quer que vá

Em busca de um melhor momento

Pra te dar

E quando você se machuca

Quem mais sofre a sua dor?

Quem foi que te trouxe ao mundo

Só pra dar amor?

Mãe! Deus te acompanhe mãe

Não! Não tenha medo não

Ah! Esqueça a ingratidão

Fique certa, Deus também guardou

Você no coração

Mãe - Gravada por Rick \& Renner (2004)

Link para ouvir a música: https://www.youtube.com/watch?v=ycn n_1CZOaM

Mãe, hoje eu descobri que eu cresci

É que de repente eu me vi 
Tão sozinho na estrada

Mãe, hoje eu precisei de você

Eu não sabia o que fazer

Me vi de mãos atadas

Mãe, o que é que a gente faz

Quando o sucesso não traz

A paz que a gente procura?

Mãe, hoje aqui sozinho eu rezei

Aqui no meu cantinho eu chorei

E chorando fiz uma jura

Juro que a partir de hoje eu vou fazer meu tempo

Vou ficar mais perto do teu sentimento

Vou ficar mais perto, mãe, do teu amor

Juro não deixar jamais a minha ambição

Falar tão mais alto que meu coração

Se minha riqueza, mãe, é o teu amor

Mãe, me dá teu colo

Mãe, mulher que adoro

Mãe, se existo devo a ti meu respirar

Mãe, tão puro amor de mãe

Que às vezes não me vêm palavras pra expressar

Mãe, pra ti conjugo o verbo amar

Mãe, teu conselho me orienta

Teu carinho me alimenta

Da paz, do amor, da esperança

Mãe, hoje eu sou um homem, eu sei

Mas às vezes que eu chorei

Não passei de uma criança

Data de Recebimento: 30/04/2013

Data de Aprovação: 27/06/2013 
Para citar essa obra:

DOS SANTOS, Maciel Francisco; DA SILVA, Telma Domingues. Sujeito histórico e amor eterno: a significação da figura materna em músicas sertanejas. RUA [online]. 2013, no. 19. Volume 2 - ISSN 1413-2109. Consultada no Portal Labeurb - Revista do Laboratório de Estudos Urbanos do Núcleo de Desenvolvimento da Criatividade http://www.labeurb.unicamp.br/rua/

Capa: Kolonj. s.d. Disponível em: <http://cfile22.uf.tistory.com/image/152B0F414F01C3F61E4F31>

Laboratório de Estudos Urbanos - LABEURB

Núcleo de Desenvolvimento da Criatividade - NUDECRI

Universidade Estadual de Campinas - UNICAMP

http://www.labeurb.unicamp.br/

Endereço:

LABEURB - LABORATÓRIO DE ESTUDOS URBANOS

UNICAMP/COCEN / NUDECRI

CAIXA POSTAL 6166

Campinas/SP - Brasil

CEP 13083-892

Fone/ Fax: (19) 3521-7900

Contato: http://www.labeurb.unicamp.br/contato 